Tugas Individu

Dosen Pengampu : Jusmawati, S.Pd.,M.Pd

Mata kuliah : Pendidikan Matematika II

\title{
VOLUME LIMAS SEGITIGA
}

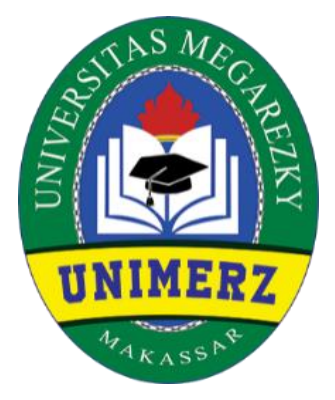

Di susun oleh

NURFITRI

(18093188206021)

FAKULTAS KEGURUAN DAN ILMU PENDIDIKAN (FKIP)

PROGRAM STUDI S1 PENDIDIKAN GURU SEKOLAH DASAR (PGSD)

UNIVERSITAS MEGAREZKY

$2020 / 2021$ 


\section{KATA PENGANTAR}

Puji syukur kita panjatkan kehadirat Tuhan Yang Maha Esa, Karena atas karunianya sehinggah saya bisa menyelesaikan penyusunan makalah yang berjudul "VOLUME LIMAS SEGITIGA”. Penulisan ini merupakan salah satu tugas mata kuliah Pendidikan Matematika II.

Dalam penulisan makalah ini saya merasa masih banyak kekurangan-kekurangan baik pada teknis penulisan maupun materi, mengingat akan kemampuan yang saya miliki. Untuk itu kritik dan saran dari semua pihak sangat kami harapkan demi penyempurnaan pembuatan makalah ini.

Akhirnya saya sebagai penulis berharap semoga allah memberikan pahala yang setimpal pada mereka yang telah memberikan bantuan, dan dapat menjadikan semua bantuan ini sebagai ibadah, Amin yaa Robbal'Alamiin

Pompanua, 08, Februari 2021 


\section{DAFTAR ISI}

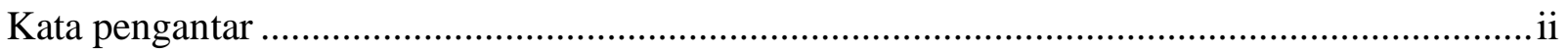

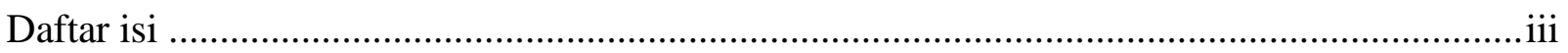

\section{BAB I PENDAHULUAN}

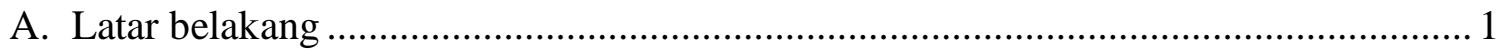

B. Rumusan masalah ........................................................................................ 1

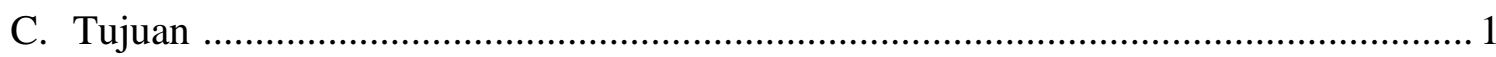

\section{BAB II PEMBAHASAN}

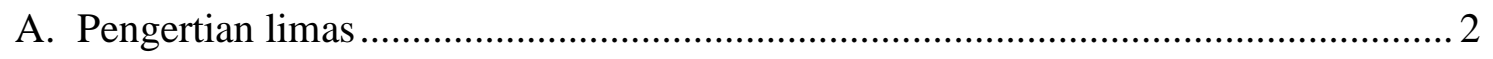

B. Unsur dan sifat limas segitiga ...................................................................... 2

C. Model, Metode, Strategi, Dan Pendekatan Yang Cocok Dengan Matari Volume

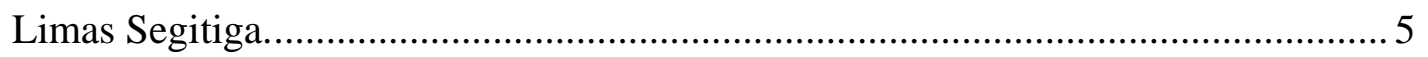

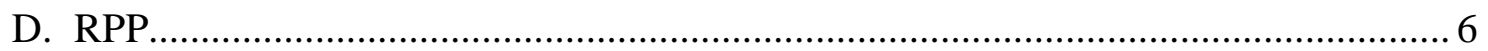

\section{BAB III PENUTUP}

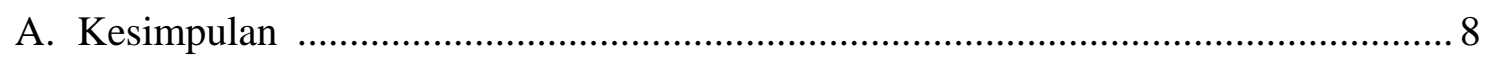

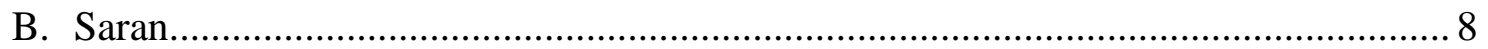

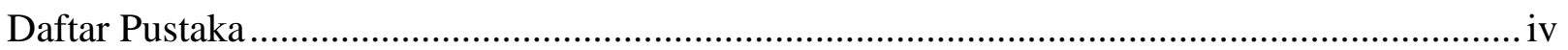




\section{BAB I \\ PENDAHULUAN}

A. Latar Belakang

Kurangnya pengetahuan tentang bagaimana mengimplikasikan matematika di dalam kehidupan sehari-hari, kurangnya kesiapan siswa untuk mengikuti pelajaran matematika dan kurangnya kemampuan matematika guru, menjadi kendala di dalam pembelajaran matematika. Tujuan penulisan makalah ini adalah untuk mendeskripsikan kondisi, bentuk RPP dan skenario pembelajaran Matematika di kelas V SD dengan menerapkan model pembelajaran STAD, dengan tahapan sebagai berikut; (1) Guru membentuk kelompok, anggotanya 4 orang secara heterogen; (2) Guru menyajikan pelajaran; (3) Guru memberi tugas pada kelompok untuk dikerjakan oleh anggota-anggota kelompok. (4) peserta didik yang bisa mengerjakan soal, menjelaskan kepada anggota kelompok lainnya sehingga semua anggota dalam kelompok itu mengerti; (5) Guru memberi kuis kepada seluruh peserta didik. Pada saat menjawab kuis tidak boleh saling membantu. (6) Guru memberikan penghargaan kepada kelompok yang memiliki nilai/poin; (7) Guru memberikan evaluasi; (8) Penutup. Dapat disimpulkan bahwa dengan diterapkannya model pembelajaran koopratif STAD, dapat membuat siswa aktif dalam pembelajaran. Metode sebuah penelitian adalah langkah ilmiah untuk mendapatkan data dengan tujuan dan kegunaan tertentu.

Limas adalah salah satu bangun ruang yang ada di dalam pembahasan pelajaran matematika. Limas segitiga memiliki empatbuah sisi dengan 6 rusuk yang saling bertemu pada 4 buah titiksudut

B. Rumusan Masalah

1. Apa Pengertian Limas Segitiga?

2. Apa Saja Unsur Dan Sifat Limas Segitiga?

3. Model, Metode, Strategi, Dan Pendekatan Apa Yang Cocok Dengan Matari Volume Limas Segitiga?

C. Tujuan

1. Untuk mengetahui Pengertian Limas Segitiga.

2. Untuk mengetahui Apa Saja Unsur Dan Sifat Limas Segitiga.

3. Mengetatui Model, Metode, Strategi, Dan Pendekatan Apa Yang Cocok Dengan Matari Volume Limas Segitiga. 


\section{BAB II \\ PEMBAHASAN}

A. Pengertian Limas

Limas adalah salah satu bangun ruang yang ada di dalam pembahasan pelajaran matematika. Limas segitiga memiliki empatbuah sisi dengan 6 rusuk yang saling bertemu pada 4 buah titiksudut. Bila digambarkan maka bentuk limas segitiga akan terlihat seperti ini:

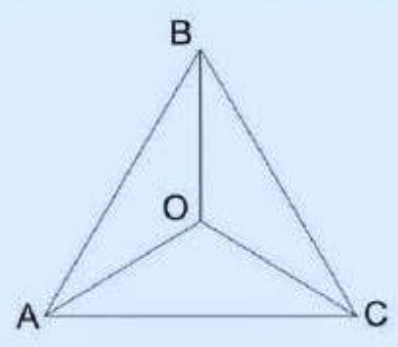

Limas segitiga adalah bangun ruang berjenis limas yang mempunyai sisi alas berbentuk segitiga. Karena alasnya berbentuk segitiga, sehingga dapat diketahui:

a. Jumlah sisi limas segitiga $=\mathrm{n}+1=3+1=4$ sisi.

b. Jumlah rusuk limas segitiga $=2 \times n=2 \times 3=6$ rusuk.

c. Jumlah titik sudut limas segitiga $=n+1=3+1=4$ titik sudut.

B. Unsur-unsur dan Sifat-Sifat Limas Segitiga

Unsur-unsur yang dimiliki limas yaitu :

- Titik sudut merupakan pertemuan 2 rusuk atau lebih.

- Rusuk yaitu garis yg merupakan perpotongan antara 2 sisi limas.

- Bidang sisi yaitu bidang yg terdiri dari bidang alas dan bidang sisi tegak.

- Bidang alas yaitu bidang yang merupakan alas dari suatu limas.

- Bidang sisi tegak yaitu bidang yag memotong bidang alas.

- Titik puncak yaitu titik yang merupakan titik persekutuan antara selimut-selimut limas.

- Tinggi limas yaitu jarak antara bidanng alas dan titik puncak.

Berikut sifat-sifat limas segitiga,

- Mempunyai 4 buah sisi berbentuk segitiga.

- Alas berbentuk segitiga.

- Mempunyai 6 rusuk.

- Mempunyai 4 titik sudut.

Jaring Jaring Limas Segitiga

Bangun ruang limas segitiga adalah sebuah bangun ruang yang memiliki alas berbetuk segitiga. Untuk memperoleh jaring jaring limas segitiga ini, kita bisa mengiris sisi sisi bagian sampingnya dan selanjutnya merebahkannya sehingga akan kamu peroleh jarring-jaring limas segitiga. 


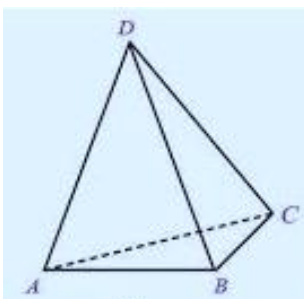

(1)

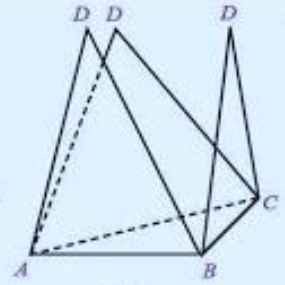

(2)

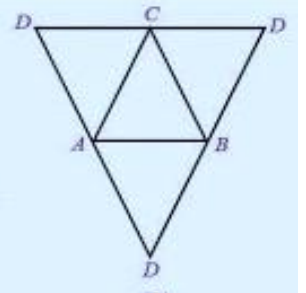

(3)

Perhatikan contoh gambar dibawah berikut ini:

Gambar disamping adalah sebuah gambar yang menunjukkan adanya proses pembentukan dari jarringjaring limas segitiga.

\section{Rumus Limas Segitiga Dan Contoh Soal}

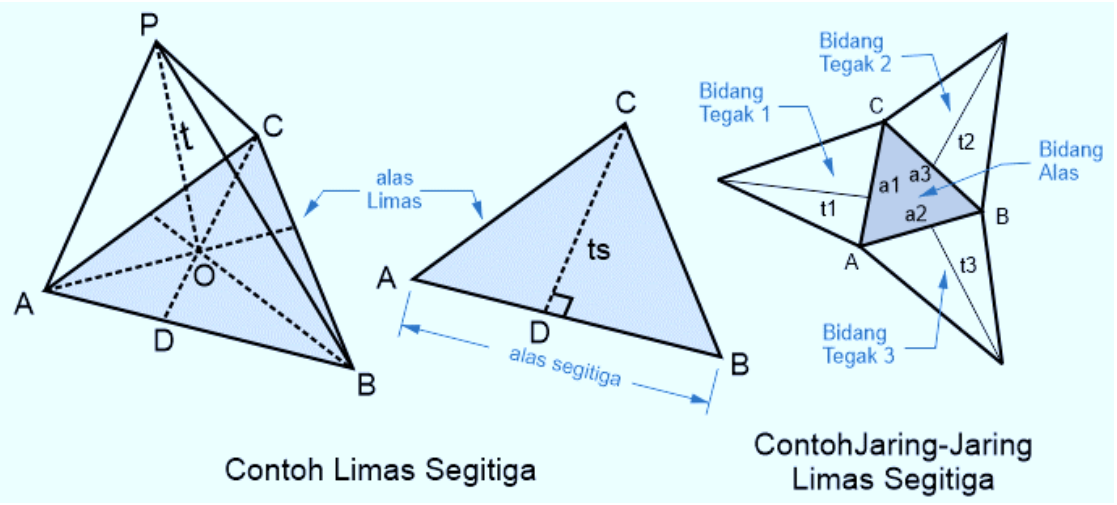

Untuk memahami rumus limas segitiga lebih mudah diperlukan pemahaman mengenai segitiga dan rumus Pythagoras.

$\mathrm{t}=$ tinggi limas $(\mathrm{PO})$

as $=$ alas segitiga $(\mathrm{AB}) \mathrm{ts}=$ tinggi segitiga alas $(\mathrm{DC})$

$\mathrm{t} 1, \mathrm{t} 2, \mathrm{t} 3=$ tinggi masing-masing bidang tegak

a1, a2, a3 = alas masing-masing bidang tegak

\begin{tabular}{|l|l|}
\hline Nama & Rumus \\
\hline \multirow{2}{*}{ Volume (V) } & $\mathrm{V}=1 / 3 \times \mathrm{La} \times \mathrm{t}$ \\
\cline { 2 - 2 } & $\mathrm{V}=1 / 3 \times(1 / 2 \times \mathrm{as} \times \mathrm{ts}) \times \mathrm{t}$ \\
\hline Luas Permukaan (L) & $\mathrm{L}=\mathrm{L}$ alas $+\mathrm{L} \Delta \mathrm{I}+\mathrm{L} \Delta \mathrm{II}+\mathrm{L} \Delta \mathrm{III}$ \\
\hline Tinggi $(\mathrm{t})$ & $t=\frac{6 \times V}{a s \times t s}$ \\
\hline
\end{tabular}




\begin{tabular}{|l|l|}
\hline Alas segitiga alas (as) & as $=\frac{6 \times V}{t s \times t}$ \\
\hline $\begin{array}{l}\text { Tinggi segitiga alas } \\
\text { (ts) }\end{array}$ & $t s=\frac{6 \times V}{a s \times t}$ \\
\hline Luas Alas (La) & $\mathrm{La}=1 / 2 \times$ as $\times \mathrm{ts}$ \\
\hline Luas $\Delta \mathrm{I}$ & $\mathrm{L} \Delta \mathrm{I}=1 / 2 \times \mathrm{a} \Delta 1 \times \mathrm{t} \Delta 1$ \\
\hline Luas $\Delta \mathrm{II}$ & $\mathrm{L} \Delta \mathrm{II}=1 / 2 \times \mathrm{a} \Delta 2 \times \mathrm{t} \Delta 2$ \\
\hline Luas $\Delta \mathrm{III}$ & $\mathrm{L} \Delta \mathrm{III}=1 / 2 \times \mathrm{a} \Delta 3 \times \mathrm{t} \Delta 3$ \\
\hline
\end{tabular}

Contoh soal dan pembahasannya

1. Hitunglah volume limas segitiga berikut ini...

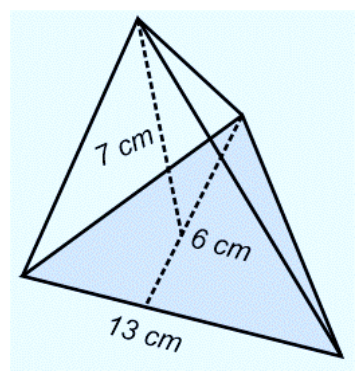

\section{Diketahui:}

$\mathrm{t}=7 \mathrm{~cm}$

ts $=6 \mathrm{~cm}$

as $=13 \mathrm{~cm}$

Ditanya:

Volume limas segitiga (V)

Penyelesaian:

$\mathrm{V}=1 / 3 \times \mathrm{La} \times \mathrm{t}$

$\mathrm{V}=1 / 3 \times(1 / 2 \times$ as $\times \mathrm{ts}) \times \mathrm{t}$

$\mathrm{V}=1 / 3 \times(1 / 2 \times 13 \mathrm{~cm} \times 6 \mathrm{~cm}) \times 7 \mathrm{~cm}$

$\mathrm{V}=1 / 3 \times\left(39 \mathrm{~cm}^{2}\right) \times 7 \mathrm{~cm}$

$\mathrm{V}=91 \mathrm{~cm}^{3}$

Jadi, volume limas segitiga adalah $91 \mathrm{~cm}^{3}$. 
C. Model, Metode, Strategi Pendekatan Yang Cocok Dengan Materi Volume Limas Segitiga Dengan menerapkan model pembelajaran STAD, dengan tahapan sebagai berikut; (1) Guru membentuk kelompok, anggotanya 4 orang secara heterogen; (2) Guru menyajikan pelajaran; (3) Guru memberi tugas pada kelompok untuk dikerjakan oleh anggota-anggota kelompok. (4) peserta didik yang bisa mengerjakan soal, menjelaskan kepada anggota kelompok lainnya sehingga semua anggota dalam kelompok itu mengerti; (5) Guru memberi kuis kepada seluruh peserta didik. Pada saat menjawab kuis tidak boleh saling membantu. (6) Guru memberikan penghargaan kepada kelompok yang memiliki nilai/poin; (7) Guru memberikan evaluasi; (8) Penutup. Dapat disimpulkan bahwa dengan diterapkannya model pembelajaran koopratif STAD, dapat membuat siswa aktif dalam pembelajaran. Metode sebuah penelitian adalah langkah ilmiah untuk mendapatkan data dengan tujuan dan kegunaan tertentu.

Menurut jusmawati (2019 : 51) Proses belajar mengajar merupakan dua konsep yang tidak dapat dipisahkan dalam kegiatan belajar dan mengajar. Belajar mengacu pada apa yang dilakukan oleh siswa, sedangkan mengajar mengacu kepada apa yang dilakukan oleh guru sebagai pemimpin belajar. Strategi pembelajaran peer lesson adalah strategi pembelajaran yang menuntut siswa belajar mandiri serta mampu menjelaskan materi kepada temannya dalam kelompok, sehingga guru hanya sebagai fasilitator yang membantu berjalannya proses belajar.

Pembelajaran volume limas segitiga dengan menggunakan pendekatan konstruktivisme dapat memungkinkan siswa untuk terlibat aktif, khususnya pada tahap eksplorasi yaitu pada kegiatan kelompok dalam menemukan konsep yang dipelajari. Hal ini menunjukkan bahwa pembelajaran volume limas segitiga dengan menggunakan pendekatan konstruktivisme dapat meningkatkan aktivitas belajar siswa. 


\section{RENCANA PELAKSANAAN PEMBELAJARAN (RPP)}

Satuan Pendidikan

Kelas / Semester

: VI/II

Mata Pelajaran

: Matematika

Materi :

: Volume Limas Segitiga

Pertemuan

$: 15$

Alokasi Waktu

: 70 Menit

1. Tujuan Pembelajaran

a. Menjelaskan bagian-bagian limas segi empat

b. Menghitung luas permukaan limas segi empat

2. Langkah-langkah pembelajaran

2.1.Alat/Bahan:

a. Alat/bahan : LKPD, Penggaris, pensil/pena dan jaring-jaring limas segitiga dari kertas karton

b. Pendekatan : konstruktivisme

c. Model Pembelajaran : STDA, Penemuan, Penyelidikan

2.2.Kegiatan Pembelajaran

\begin{tabular}{|c|c|c|}
\hline Kegiatan & Deskripsi Kegiatan & Alokasi Waktu \\
\hline $\begin{array}{c}\text { Kegiatan } \\
\text { Pendahuluan }\end{array}$ & $\begin{array}{l}\text { - Kelas dimulai dengan salam dan do’a } \\
\text { bersama dipimpin oleh ketua kelas. } \\
\text { - Mengecek kehadiran siswa dan } \\
\text { mengkondisikan siswa untuk siap belajar } \\
\text { - Menyampaikan tujuan pembelajaran } \\
\text { - Menanyakan kepada siswa: Adakah benda- } \\
\text { benda di sekitar lingkungan rumah atau } \\
\text { sekolah yang berbentuk limas segi. } \\
\text { - Menanyakan kepada siswa cara mencari } \\
\text { volume persegi dan segitiga. Dan } \\
\text { mengaitkannya dengan pelajaran yang akan } \\
\text { dipelajari. }\end{array}$ & 10 menit \\
\hline Kegiatan Inti & \begin{tabular}{|l} 
1. Membagi siswa menjadi 5 kelompok \\
- Setiap kelompok diberi nama sesuai \\
dengan nama unsur limas \\
- Setiap kelompok diberi LK serta satu \\
buah jaring-jaring limas segitiga \\
2. Guru menjelaskan petunjuk LK
\end{tabular} & \\
\hline
\end{tabular}




\begin{tabular}{|c|c|c|}
\hline & \begin{tabular}{|l} 
3. Siswa di dalam kelompok bekerja \\
mengamati, mengukur, dan mencatat hasil \\
pengukuran pada LK. \\
4. Perwakilan masing-masing kelompok \\
mempresentasikan hasil kerja kelompok di \\
muka kelas \\
5. Tanya jawab guru dan siswa tentang hasil \\
kerja masing-masing kelompok
\end{tabular} & 45 Menit \\
\hline $\begin{array}{l}\text { Kegiatan } \\
\text { Penutup }\end{array}$ & $\begin{array}{l}\text { 1. Dengan bimbingan guru, siswa } \\
\text { menyimpulkan hasil pengukuran volume } \\
\text { limas segitiga yang telah diukur } \\
\text { 2. Siswa diminta melakukan refleksi secara } \\
\text { tertulis. } \\
\text { - Hal baru apa sajakah yang kamu pahami } \\
\text { dari pembelajaran hari ini? } \\
\text { - Hal apakah yang masih belum jelas? } \\
\text { - Bagaimana perasaanmu selama proses } \\
\text { pembelajaran berlangsung? } \\
\text { 3. Siswa menempelkan dan membaca hasil } \\
\text { refleksi } \\
\text { 4. Mengakhiri pembelajaran dengan salam }\end{array}$ & 15 Menit \\
\hline
\end{tabular}

3. Penilaian
a. Penugasan (lembar kerja siswa)
b. Instrumen penilaian individu dan kelompok
c. Tes tertulis

4. Sumber Belajar

a. Senang Belajar Matematik Buku Guru SD/MI Kelas 6 cetakan ke-1 Jakarta :

Kementerian Pendidikan dan Kebudayaan, 2018.

b. Buku Matematika untuk SD/MI Kelas VI Kurikulum 2013 Revisi, Jakarta : PT. Gelora Aksara Pratama Mengetahui Kepala MIN 4 Batanghari Suhardiman, S.Pd NIP. 19700621995021001 Muara Bulian, 4 Juli 2020 Guru Matematika Qurata Aini, S.Pd.I NIP. 1978091120091 


\section{BAB II}

\section{PENUTUP}

A. Kesimpulan

Limas adalah salah satu bangun ruang yang ada di dalam pembahasan pelajaran matematika. Limas segitiga memiliki empatbuah sisi dengan 6 rusuk yang saling bertemu pada 4 buah titiksudut.

Unsur-unsur limas yaitu :

- Titik sudut merupakan pertemuan 2 rusuk atau lebih.

- Rusuk yaitu garis yg merupakan perpotongan antara 2 sisi limas.

- Bidang sisi yaitu bidang yg terdiri dari bidang alas dan bidang sisi tegak.

- Bidang alas yaitu bidang yang merupakan alas dari suatu limas.

- Bidang sisi tegak yaitu bidang yag memotong bidang alas.

- Titik puncak yaitu titik yang merupakan titik persekutuan antara selimut-selimut limas.

- Tinggi limas yaitu jarak antara bidanng alas dan titik puncak.

sifat-sifat limas segitiga,

- Mempunyai 4 buah sisi berbentuk segitiga.

- Alas berbentuk segitiga.

- Mempunyai 6 rusuk.

- Mempunyai 4 titik sudut.

B. Saran

Makalah ini masih jauh dari kata sempurna dikarenakan keterbatasan pengetahuan penulis akan tetapi maklah ini bisa memberikan sedikit gambaran mengenai volume limas segitiga dan penjelasannya. Semoga makalah ini dapat barguna bagi pembaca. Diperlukan adanya kritik terhadap makalah ini agar dapat memperbaiki makalah berikutnya. 


\section{DAFTAR PUSTAKA}

https://rumusbilangan.com/jaring-jaring-limas-segitiga-segi-empat-segi-lima-segi-enam/

https://www.advernesia.com/blog/matematika/rumus-limas-

segitiga/\#: :text=Limas\%20segitiga\%20adalah\%20bangun\%20ruang,mempunyai\%20sisi

\%20alas\%20berbentuk\%20segitiga.\&text=Jumlah\%20sisi\%20limas\%20segitiga\%20\%3 D\%20n,2\%20\%C3\%97\%203\%20\%3D\%206\%20rusuk.

Jusmawati, J., \& HS, E. F. (2019). Peningkatan Aktivitas Pembelajaran Matematika Melalui Model Pembelajaran SFAE Pada Kelas IV SD Inpres Bangkala III Makassar. Media Pendidikan Matematika, 7(1), 51-57. 